\title{
Ups and downs of art commerce: narratives of "crisis" in the contemporary art markets of Russia and India
}

\author{
Nataliya Komarova ${ }^{1}$
}

Published online: 18 September 2017

(C) The Author(s) 2017. This article is an open access publication

\begin{abstract}
This article develops an analytical framework to study the role of narratives in markets and argues that there is a relationship between the structure and composition of narratives produced by market actors and market dynamics. With respect to theory, the article bridges the perspectives that study markets as cultures and as fields and draws from the organizational studies approach to the analysis of narratives. Two empirical cases of the crises narratives in the emerging contemporary art markets of Russia and India illustrate the use of the framework. The analysis is based on in-depth interviews with artists and art dealers as well as observations in Moscow, Saint Petersburg, New Delhi, and Mumbai conducted between April 2012 and June 2013. The article shows that there is a widely shared crisis narrative with a coherent structure in the Indian art market. In contrast, fragmented and contested stories that lack narrative structure dominate in the Russian art market. The analysis of the first case highlights the narrative structure and shows the productive work it does in the Indian market - it provides a moral justification of existing market norms and produces a perspective for the future. The analysis of the second case focuses on the context of narrative production and connects the conflicting interpretations of the crisis in the Russian art market to contested hierarchies and persistent uncertainty.
\end{abstract}

Keywords Antenarrative - Indian art market $\cdot$ Market narrative $\cdot$ Market as culture $\cdot$ Narrative analysis $\cdot$ Russian art market

Market actors tell stories: how they are better than their competitors, how a product is of an outstanding quality, how a company or industry is developing. These stories are aimed at customers, competitors, or even themselves (and researchers) and serve as sense-making tools. Exploring the production and circulation of meanings (Velthuis 2005; Zelizer 2010) or

Nataliya Komarova

n.komarova@uva.nl

1 Amsterdam Institute for Social Science Research, University of Amsterdam, Postbus 15718, 1001 NEAmsterdam, The Netherlands 
limited rationalities of social actions in markets (Abolafia 1998) scholars often use stories or narratives produced by market actors as a methodological tool. But it is only recently that narratives in a market and the role they can play in economic processes have become a more deliberate focus of attention (e.g., Blinder et al. 2008; Fligstein et al. 2014). Thus Alexander (2011) argues that shared narratives enable particular agencies of market actors and create certain expectations for their audiences. This article builds on this proposition and develops an analytical perspective to study the role that narratives play in markets' development. It suggests that a close analysis of a narrative structure and the conditions in which market actors succeed (or fail) to produce a narrative allows understanding how cohesion and stability are achieved in a market. The article argues that there is a relationship between the structure and composition of narratives produced by market actors and market dynamics.

To develop the methodological framework for studying market narratives, the article builds on the two theoretical streams of market studies - the one that approaches markets as cultures (Fourcade and Healy 2007; Wherry 2014; Zelizer 2010) and the one that looks at markets as fields (Bourdieu 1989; Fligstein 2002; Beckert 2010)_arguing that taken together they allow for a necessary comprehensive approach. It further employs the tools of the narrative tradition in social analysis (Maines 1993; Alexander and Jacobs 1998) and the field of organizational studies where narratives have already become a common object of research of formal organizations (Cunliffe et al. 2004). The focus on narratives is essential for understanding organizations as systems of meanings (Morrill and Fine 1997). And while there is a growing awareness that markets and formal organizations share many characteristics (Ahrne et al. 2015), market scholars have not widely looked at narratives to understand how meaning making affects economic processes or specific markets (see Beckert 2013 as one of a few exceptions).

To illustrate the work of the proposed analytical framework this article considers an empirical case of emerging contemporary art markets presuming that it will illuminate the role that narratives play in markets more generally. It proceeds from the assumption that due to the extreme levels of ambiguity that these markets are exposed to, more than in other contexts, they depend on narratives that allow coping with the fundamental uncertainty of economic action and create confidence in market development (Beckert 2013; Alexander 2011). Art markets are not just dealing with incommensurable unique products (Karpik 2010), but in the early stages of development status hierarchies are easily contested, organizations are relatively young and their routines are not yet stabilized.

More specifically the article looks at the emerging art markets of Russia and India, where I did my fieldwork from April 2012 to June 2013. Every art dealer or artist I have met in Russia and India during that period had an opinion about the art market in a state of crisis. The "crisis" was a point of reference in explaining what was going on. In a way, an art market crisis became a sense-making tool and cultural phenomenon within the two art worlds (the same way as the financial crisis of 2008 became a cultural phenomenon in the wider globalized society, see Roitman 2014). Therefore, due to the prominence of this topic in the studied environments I have narrowed down the focus of the article to the different stories about the crises ${ }^{1}$ filling the two art scenes and the way they are related to the developments of the markets.

\footnotetext{
${ }^{1}$ The terms "narrative" and "story" are used somewhat interchangeably here. Yet, the first concept refers to specific theoretical perspective developed further in the article. Whenever the term "story" is used, it is likely to indicate the lack of properties required to treat it as a narrative is the strict sense.
} 
The aim of looking at market narratives in the two contexts is not comparison per se, but observing the possibility of diversity in the way narratives are developed and the performative work they do. Thus, the structures of crisis narratives in the two countries differ significantly. In India one shared narrative with a clear sequenced structure can be found. In Russia, on the contrary, there are at least two competing ways to speak about the country's art market crisis that each largely lack narrative structure and the actors are often ambiguous. Although in India the stories about the crisis have a "happy ending." there seems to be no ending of the "crisis" in the Russian art market.

The focus on crisis narratives in the two emerging art markets, as a specific instance of a market narrative, was coincidental and imposed by the field and mainly serves the function of an illustration of the work of the analytical framework developed further. Yet the article also makes an empirical contribution to the body of empirical research on the role of crisis in the contemporary art world (and other domains of economic life more generally). The crisis of the global art market has been an important topic discussed in many professional media and industry reports (see, for example, in Artprice 2009, 2011; ArtTactic 2009; Evans 2008; Hernando 2011; McAndrew 2010; Velthuis 2011, etc.). These publications understand crisis as a sudden drop in volumes of sales and levels of prices and employ auction sales figures to draw their conclusions. ${ }^{2}$ This perspective, however, can hardly say anything about what a crisis means for the actors of an art market themselves and for their activities. Instead of looking for an objective measure of an art market crisis, this article proposes an interpretative approach that looks at variations in perceptions of crisis among art market actors and shows the relation between the different narratives about the crisis and the dynamics of an art market.

Finally, the article also contributes to existing studies of emerging art markets. While a number of new contemporary art markets from different parts of the world caught wide attention of the international art communities in the past twenty years (see, for example, Goodwin 2008; McAndrew 2009; Robertson 2011), in depth academic research into how these new art markets develop is still limited (see, for example, Poulsen 2012; Ithurbide 2014; Komarova 2015; Sooudi 2015-for India and Milam 2013; Kharchenkova et al. 2015; Komarova and Velthuis 2017-for Russia). By looking at the Indian and Russian art market narratives, the article shows how actors of emerging markets make sense of their environment and recent history.

\section{Narratives in markets}

Economic views on markets that consider them exclusively in terms of pure competition and spontaneous interrelations between demand and supply have been questioned many times (cf. Fligstein 1996, 2002). A market is "organized" (Ahrne et al. 2015): there are hierarchies and rules within markets, and they have systematic and more or less formalized relationships among producers, suppliers, customers, and governments (Baker 1990). One of the central questions of economic sociology is how these diverse

\footnotetext{
${ }^{2}$ While public auction sales reflect the performance of the art market, they disregard the primary market, i.e., of gallery sales where the biggest part of contemporary art is circulated. Moreover, often there are no auction data on a national level as the biggest auction houses operate internationally. Thus, these numerous articles and reports do not sufficiently shed light on the experience of crisis in the contemporary art sector or within different countries.
} 
social relationships and specific social structures affect market processes and economic output (White 1981; Granovetter 1985; Fligstein 1996; Dobbin 2004). Thus, understanding market as a social field (Bourdieu 1989; Fligstein 2002; Beckert 2010) focuses on hierarchies and social actions of market participants within a system of domination necessary to stabilize the market (e.g., eliminate pure price competition). "Conceptions of control," which are dominant interpretative frameworks that structure perceptions of how market works, are a crucial element of these systems of domination. While this perspective acknowledges the importance of "collective fictions" (Beckert 2013; Wherry 2014) in market organization, it rather focuses on the contexts in which these symbolic systems are produced, but often overlooks their embeddedness in wider cultural realms (Wherry 2014) and internal structuring logic that result in their relative autonomy and causal power (Alexander and Smith 2001; Beckert 2010).

An alternative markets-as-cultures perspective emphasizes the role of "meaning systems of norms, rules and cognitive scripts" in the structuring of markets (Abolafia 1998, p. 69). It pays attention to the local rationalities of markets under consideration in order to explain the variation in configuration of markets of various goods and services (cf. Almeling 2011; Chan 2009, 2012; Velthuis 2005), in different places (cf. Wherry 2008), at different times (cf. Zelizer 1979). It shows how myths, symbols, and beliefs shape markets and influence actions in markets (Wherry 2014). Such focus allows paying attention to stories filling the markets via media publications, written artifacts of the market or in-depth interviews with market participants (see, for example, Anteby 2010; Bandelj 2008; Khaire and Wadhwani 2010).

In spite of the frequent use of narratives as a subject of analysis, the sociology of markets rarely explicitly focuses on the role of narrative in the market-its formal properties and dynamics. Few exceptions exist. For example, McCloskey looks at economic theory as a peculiar form of narrative circulating in markets (1990). Similarly, Fligstein et al. (2014) show how the dominance of macroeconomics as a main interpretative framework and inability to construct a new narrative that would embed unfolding events caused inadequate reaction of financial regulators to the economic crises of 2008. From a more theoretical perspective, Beckert discusses one function of market narratives, i.e., narratives' possibility to construct fictional expectations in the economy necessary to manage uncertainty natural to economic exchanges (2013). Theorizing the importance of the cultural dimension of a market functioning Alexander proposes to understand any market as a narrative where "actors engage in performances that project meanings" for each other as well as audiences of potential buyers, investors, and art collectors (2011, p. 484).

Although these works raise relevant issues and provide methodological tools for a study of a market narrative, none of them has developed an elaborate analytical approach. This article, in contrast, proposes that such approach will allow deeper understanding of meaning making processes in markets and markets' dynamics. Developing this framework, the article brings together the markets-as-cultures perspective that prioritizes narrative structure and markets-as-fields perspective that focuses on the conditions of production of a narrative. To elaborate, I use the insights from organizational studies literature that has a deeper and longer record of engagement with narrative analysis. Although markets and (formal) organizations are often opposed to each other in scholarly literature, they share many characteristics (Ahrne et al. 2015). Thus, markets get "organized" via construction and performance of narratives. 


\section{Narrative as structure and action}

Narratives are important elements of "cultural structure" of any community (Alexander and Smith 1993). In organizations, they serve as sense-making tools both for participants of these organizations (or narrators) and their audiences (Abolafia 2010). Participants in markets - sellers, mediators, and buyers - also find themselves in a situation of uncertainty and cognitive deficit and have to make sense of the processes around them by producing or perceiving a narrative. Elements of a story form a narrative in case they are "culturally salient material[s] generally agreed upon by members of the producer's culture to be self-evidently important and true" (Polanyi 1979, p. 207). Therefore, a narrative should be grounded in meanings shared by a relevant community. Narratives can be analyzed either as structures (Boje 2001) or as actions (see, for example, Cunliffe and Coupland 2012; Smith 1980).

Narrative structure requires attention, as narratives are not just stories. They demand a certain rationality of coherence (Fisher 1985). One of the most important properties of a narrative is its sequenced nature (White 1980) that implies casual relationships between the elements of a story (Riessman 1993). A limited number of relatively simple plots serve as containers to sort otherwise incomprehensible flow of events (White 1973). A narrative suggests an observant position of a speaker and thus it is often told in third person. A complete narrative ends with a new state of the situation (White 1980). This rigid structure allows making sense of a constellation of events and transactions and reflecting on one's own position in relation to them and therefore provides "a sense of historical continuity" between the abstract events that constitute a narrative and actions of a narrator (Alexander and Jacobs 1998). At the same time, the universal properties of a narrative allow "for intersubjectivity and cross communication between different publics" (ibid.).

Since a narrative with its rigid structure shapes speech in a certain way, this means that it is inevitably a selective representation of experiences. Therefore, it is also important to analyze it as an action (of selection). Narratives are perspectives that include ideologies of narrators (Gee 1991). A narrator constructs the story to explain his or her point of view about market development using some facts while neglecting others (McCloskey 1990). The collective act of narrative construction prioritizes one interpretation of events over all others (Abolafia 2010). By choosing a collective narrative to elaborate on an actor relates to a certain (imagined) community and its set of values. This allows having an opinion and evaluating ones' actions even if they did not participate in the key events that constitute a narrative (Alexander and Jacobs 1998). Thus, a narrative "makes sense," but also "gives sense," by legitimating and normalizing a certain attitude (Cunliffe and Coupland 2012, p. 66). In this respect, what remains untold is also a meaningful part of a narrative.

Just as "social actions, movements and identities are guided by narrative understandings" (Alexander and Jacobs 1998) embedded in "stories, plots [with] beginnings, middles, and ends, heroes and antiheroes, epiphanies and denouncements, dramatic, comic and tragic forms" (Alexander and Smith 1993), a shared narrative guides actions in markets. Narratives are "powerful because we utilize them to determine, justify, and guide our lives" (Cunliffe et al. 2004, p. 263). The sequenced structure of a narrative creates a temporal perspective for market development. Performances of a market narrative "are accepted as promises" by their audiences and therefore they allow 
markets to function successfully (Alexander 2011, p. 484). According to this approach, the construction of narratives creates expectations about the future as "known present and the opaque future can become connected by the proper narrative arc" (ibid.). In other words, fictional expectations about the future (Beckert 2013), retranslated in a narrative form, supposedly allow coping with the fundamental uncertainty of economic action and create confidence in market development.

\section{Narrative production}

Nonetheless, is there always a single coherent narrative to be performed by a market actor and analyzed by a researcher? In an article about market as narrative (2011) Alexander emphasizes the performative function of a narrative and proceeds from the assumption that it is always there. Yet, organization studies scholars argue that a narrative takes time and effort to be constructed (Abolafia 2010). Therefore, unlike in fiction, stories performed in an organization or a market are not necessarily complete narratives: the plot might be unspecified, heroes and villains not determined, facts and events not yet linked in a compelling way. Moreover, more than one narrative can compete for dominant interpretation of events and win or lose over time, which affects the strength of its structural elements (Alexander 2002).

The ability to produce and support a coherent narrative is related to social hierarchy and power. When no agent has an amount of authority necessary to impose a certain interpretation of events over the whole organization or market, then multiple narratives are possible and different communities of interpretation exist (Cunliffe et al. 2004, p. 265). And when those who are just striving for a more prominent position in a community (or market) are having a chance to engage in a symbolic struggle over imposing an alternative legitimate vision of the world (Bourdieu 1989), a conflict of narratives becomes more explicit. This creates a polyphony- "multiple, alternative and contested narratives and stories" (Cunliffe and Coupland 2012, p. 64). When actors have different competing stories to tell about the same event or create different causal links to explain them, then existing interpretations are harder to fit into a narrative form. As a result, polyphonic stories can have some properties of a narrative but lack others.

Narrative as a rigid communicative form is often opposed to various "others" that are not so demanding: for example, a story or a discourse. Thus, to distinguish between complete narratives and fragmented stories we can look at the distinction made by Hayden White, who introduces the concepts of the discourse that narrates and the discourse that narrativizes, i.e., produces a coherent story. The former is linguistically subjective, while the latter demands objectivity. Narrativizing discourse does not have a narrator, i.e., "events speak for themselves" (White 1980). Shared by a community, a narrative gets uniform and its elements are repetitively reproduced. "The absence of narrative capacity or a refusal of narrative" is "an absence or refusal of meaning itself" (ibid., p. 6). Thus, when a story lacks coherence or clear plot, its capacity to sustain shared meanings and guide consistent actions in the market is also limited.

As another alternative to a linguistically demanding narrative, Boje suggests a concept of antenarrative (2001) to study fragmented stories that do not have a clear narrative structure. Antenarrative is both before the narrative and something that resists it. It is ambiguous, plurivocal, non-linear, and non-complete. To study an antenarrative, one has to re-contextualize it and pay attention to time, place, and intentions of a 
storyteller, in other words look at the field in which it is being produced. Boje is interested in the intertextuality of stories as relationships among the stories of different communities symbolically unfold their social positions and political stands.

Nevertheless, this analytical distinction is too strict in itself and therefore can be misleading. Maines claims "all narratives are ultimately incomplete" (Maines 1993, pp. 21-22). There is no need to distinguish between a narrative and its opposite, since all the analyzed speech acts contain some elements of a narrative and lack others and rather than a dichotomy this distinction can be seen as a continuum of possibilities. Therefore, this article suggests that any story can be studied from within (its narrative structure or the lack of it) and from the outside (its context and relationship to other stories).

Moreover, "narratives exist at various levels of scale, ranging from the personal to the institutional, to the cultural" (ibid.). In the example of the civil society, Alexander and Jacobs (1998) argue that the general shared narrative dominates over personal narratives when a field that produces it has (or demands) sufficient autonomy. Thus, the extent to which a narrative observed in a market is shared and consistently reproduced by its actors can indicate the level of development and autonomy of this market from wider spheres. At the same time the lack of a general shared narrative therefore would indicate a lack of market coherence and autonomy, since shared meanings cannot be distributed through this narrative. Such market would be filled with incommensurable or conflicting understandings of its functioning and multiple market cultures would coexist (Zelizer 1999). These market cultures can be analyzed from the "antenarrative" perspective, which suggests a focus on the interrelationship between existing stories and on the contexts of their production. Whether a market consists of independent circuits of commerce (Zelizer 2010) or undergoes a struggle for domination (Fligstein 2002) becomes a matter of empirical inquiry via studying the stories that structure these markets.

The empirical case I analyze here aims at illustrating the theoretical framework developed above. Two contemporary art market narratives differ in the level of consistency - one market performs a developed structured narrative, while the other lacks a single narrative and instead contains multiple incomplete stories. Therefore, the focus of analysis of each of the two narratives also differs. The example of the Indian art market narrative is taken from a more internal perspective of analysis that shows how actors historicize market development, distinguish between heroes and villains, and create positive expectations of the future. The example of the Russian contemporary art market provides the opportunity to look at the competing stories and the context of their production, thus emphasizing a more external perspective.

\section{Narratives in art markets}

Contemporary art market is a vivid example of what Aspers (2009) calls a status market in which there is no universal standard for evaluation of a product defined by market authorities. Instead, evaluation depends on a relative position of actors (their status rank) involved in a transaction. This type of market requires high levels of social involvement in its coordination and intensive knowledge production. Thus, starting from the classical studies of art markets, scholars have emphasized that, in contrast to the markets for established art, the markets for works of living artists are commonly characterized as markets with a high degree of uncertainty (Moulin 1987; Peterson 1997; Horowitz 2011; Beckert and Rössel 2013). Ever since the market 
became a dominant form of distribution of new art, the criteria over what constitutes good and valuable art became vulnerable and contested, since evaluating and gatekeeping power has moved from one central agency (such as the Art Academy) to multiple independent market actors (White and White 1965). Apart from being a necessary element of creativity and innovation (Menger 2014), uncertainty forces all art market actors to perform additional work to be sustainable. High occupational risks and uncertainty of the outcome of artistic labor forces artists to implement "insurance devices" into their career strategies (Menger 1999). Value of unique artworks has to be constituted in situ and consequently depends on social relations and shared meanings, established conventions and multiple judgment devices (Becker 1984; Velthuis 2005; Karpik 2010). Emerging markets are supposedly exposed to even higher levels of uncertainty, since conventions and routines are still to be established, durable trustful relationships to be developed. ${ }^{3}$

To reduce this uncertainty art market participants are constantly engaged in the production and support of narratives in many ways. They give interviews and publish numerous press releases, catalogues, news reports, etc. They produce narratives about artworks by constructing provenances and discussing artists' biographies, gallery brands, and the art market in general. All these activities contribute to the construction of market narratives that should embody "knowledge and confidence about the future," which is culturally necessary to stabilize a community and enhance actions in the market (Alexander 2011, p. 484). Art dealers tend to "believe in their artists," see "new aspiring collectors" coming in the market, or a lot of "potential" in the art market, etc.

Yet, existing studies of art markets rarely focus on the processes of meaning making (for exceptions see, for example, Khaire and Wadhwani 2010; Komarova 2015). An exemplary analysis of narratives in the art market can be found in Velthuis's study on pricing strategies in Amsterdam and New York (2005, p. 132-157). He distinguishes an "honorable," a "superstar," and a "prudent" narrative about the way we should price artworks. Different narratives have different plots. They are performed by different communities (more consecrated and avant-garde vs. more commercially oriented art dealers) and dominate the market in different times: thus, a "superstar" narrative gains prominence during boom periods of the market, while a "prudent" narrative is more salient in recession periods (Velthuis 2010).

While Velthuis discusses functions of the narratives that he identified, he does it descriptively on the level of narrating individuals. He understands narratives as sensemaking tools for art market participants. Narratives that art dealers perform and defend allow some and limit other possibilities of pricing approaches in correspondence to shared values of a community expressed through them. Narratives allow people to identify themselves through shared moral standards and at the same time distinguish themselves from others. Velthuis does not look at the role that narratives play in the market as a whole (its performance and development) and therefore does not discuss relationships between the identified narratives. For instance, protagonists of one narrative can be villains of the other or the same actors can perform different narratives in

\footnotetext{
${ }^{3}$ The lack of qualitative research on this topic does not allow making a stronger claim, however, during my fieldwork artists, art dealers, and even art collectors from both Russia and India kept repeating that they had to learn "on the go," that the market is "wild" and unregulated, that norms and rules from established markets "do not apply here," etc.
} 
different times. Therefore the relationships among the narrators have to be unpacked in detail. Why do narratives differ? What are the power relationships that art market participants defend in these narratives? In addition, the perspective elaborated above requires a closer focus on the structure or coherence of the stories found in the art market. Stories that art market participants tell can be fragmented, non-linear, without a clear plot and identifiable characters. Do such stories fully perform the function of a sense-making tool? Do meanings expressed in such stories guide actions or create some form of cohesion in the art market? The lack of temporal dimension in a story, for example, may not allow formulating possible expectations of the future and affect the dynamics of the market.

Despite frequent arguments about progressing globalization of the contemporary art world (e.g., Bydler 2004; Crane 2009), empirical research still shows dramatically unequal access of artists from the majority of (and especially emerging) art scenes to the centers of art commerce and valuation (Quemin 2006). The homogenizing effect of the global art world is overestimated (Velthuis and Curioni 2015). With exception of the top artists and art galleries, art scenes and markets remain primarily domestically bound and are undergoing their own dynamics. Therefore, it is not very useful to study these markets from a universalizing perspective that looks for global trends and compares performance of presumably similar institutions, as the majority of professional accounts that look at emerging markets do (see, for example, McAndrew 2009; Robertson 2011; Kraeussl and Logher 2010). I argue here instead that the specific dynamics of national art markets (both established and developing) can be uncovered from within - by looking at the product of the meaning making activities of art market participants - the structure and coherence of the stories that "explain" the market.

\section{Narrativizing power of crisis}

The empirical part of this article focuses on stories about crises in the two developing art markets that came up as dominating interpretations of the ongoing events. While the choice of this plot can be seen as arbitrary, there is also evidence that the concept of "crisis" can be a particularly convenient sense-making tool. Thus, Roitman (2014) argues that narratives of crisis in contemporary societies become devices "to understand how to act effectively". She explains the power of the concept through its impelling rhetorical structure: "Evoking crisis entails reference to a norm because it requires a comparative state for judgment" (ibid, p. 4). Crisis always suggests a certain structure of temporality, since it establishes a turning point and a reference to the previous non-crisis situation. "Crisis-claims evoke a moral demand for a difference between the past and the future" (Koselleck 2000; cited in Roitman 2014), hence discourses of crisis imply normativity. Finally, crisis discourse contains a question: "What went wrong?" The question implies a critical judgment and puts the speaker in the position of an observant. All these properties of the notion make it particularly suitable for narrativization. As a result, stories of crisis have become powerful in contemporary society in general (Roitman 2014) and salient in the art markets of Russia and India as well.

The data analyzed in the empirical part of this article were collected four years after the global financial crisis of 2008. Yet, participants of the two art markets still very frequently interpreted the ongoing processes of these markets in relation to the effects and aftermath of that crisis. This larger crisis was a universally shared starting point to elaborate on specific dynamics of the crises in the markets. Alexander and Jacobs 
(1998, p. 23) explain that narrative elaboration of crises- "understood as social dramas - is crucial for providing a sense of historical continuity in the crisis bound, episodic constructions of universalistic solidarity that continually form and reform civil society." On the level of a market crisis narratives serve the same function. The sense of historical continuity is something that especially emerging markets are missing, due to the short period of their operation and lack of official meta-narratives produced by scholars, experts, and media.

In the empirical analysis of the crises narratives Alexander and Jacobs (ibid.) focus on diverging emplotments of characters and events shaped by different common codes of higher level. In a similar vein, an approach developed here is interested in shared or oppositional readings of markets' development by their participants. Therefore, this article is not looking at prices and volumes of sales and making any conclusions about the objective state of the art markets in Russia and India. Instead, it analyses the perceptions of market crises and argues that they are telling something about the "real" crises in the studied contexts only to the extent that they have performative power and are guiding actions of market participants.

\section{Narrative data and narrative method}

I analyze here two cases of market narratives in the emerging contemporary art scenes of Russia and India. We can view the selection of cases as theoretically driven because the two contexts represent, to a certain extent opposite narrative situations and therefore allow highlighting the dual nature of the developed theoretical framework. Thus, in one case, it is easy to observe a shared and coherent narrative with elaborate structure. In the other case, several interpretations of the crisis oppose each other and observed stories are not well structured. Performers of alternative stories are not always consistent in which perspective they adhere to. The analysis of the first case pays most attention to the narrative structure and the role it plays in the interpretation of market events. The analysis of the latter case focuses on the lack of narrative structure, on the context of production of opposing interpretations of the market crisis and related market strategies.

The analysis mainly draws upon qualitative interview data collected in the centers of art commerce of two countries - in New Delhi, Mumbai, Moscow, and St. Petersburg-from April 2012 to June 2013. I draw from the pool of in-depth interviews with over 140 various art market participants (e.g., artists, art dealers, collectors, art critics and journalists, auctioneers, and directors of art museums, fairs, and foundations). In this article, I primarily focus on the production side of the primary art market and analyze interviews with those whose primary profession we can identify as artists and art dealers (see Table 1). ${ }^{4}$ In addition, in the same period, I carried out ethnographic observations in those cities. In particular, I attended educational events for collectors, press conferences, art fairs, and openings of exhibitions and residencies. These secondary observations help in interpretation of the interview data.

The overall project had an exploratory character. Therefore, the selection of interviewees was informed by a maximal variation sampling strategy. I started with an initial list of galleries I wanted to approach in each country (around seventy in Moscow and

\footnotetext{
${ }^{4}$ As often happens, in many cases art market actors in these countries share multiple professional identities.
} 
Table 1 Number of interviewed artists and art dealers per city

\begin{tabular}{llll}
\hline & Artists & Art dealers & \\
\hline Moscow & 22 & 18 & 40 \\
St. Petersburg & 2 & 11 & 13 \\
New Delhi & 14 & 23 & 37 \\
Mumbai & 3 & 13 & 16 \\
& 41 & 65 & 106 \\
\hline
\end{tabular}

The varied numbers of interviewees were caused mostly by practical constraints. I spent twice as much time in New Delhi as in Mumbai and the same goes for Moscow and St. Petersburg. Moreover, St. Petersburg data collection rate fell for the summer season, when the art scene was practically sleeping and most of the potential interviewees were away on holidays. Yet, the St. Petersburg commercial art scene is considerably smaller than the one in Moscow, which also explains the number of interviewees

Saint Petersburg and around ninety in New Delhi and Mumbai). Due to the lack of official art market directories in both countries, the list was compiled based on a number of publically available sources, ranging from international data bases (such as ArtFacts.net) to local travel guides. Prior to fieldwork I emailed every gallery on the list and started interviewing based on the initial response. While in the countries I asked for recommendations, approached artists, art dealers, and their assistants at the variety of art events, such as art fairs, open days at art schools and residencies, and exhibition vernissages. In approaching artists and art dealers I aimed for diversity in terms of type of art (more traditional canvas paintings vs. multi-media installations), length of presence in the market, national and international success. Therefore, this sample includes internationally known artists, who exhibited at such events as the Venice biennale and artists who have just graduated from an art academy and have their first solo exhibition in a municipal vanity gallery. The galleries vary between those that have been operating for over fifty years and participated in the Art Basel fair, and those, which opened only half a year before the interview or aim at local buyers only.

The interviews lasted between $40 \mathrm{~min}$ and $2.5 \mathrm{~h}$ and focused on a number of topics, such as individual strategies in the art scene and the market, relationships with other key market participants, aims, and ambitions, as well as their views on the overall market development. While the primary focus of the interviews was on individual practices of the interviewees, they naturally interpreted them in the light of wider events of the art markets in order to explain their position. These data are a primary focus of analysis. Interviews in Russia were conducted in Russian and the interviews in India were in English. ${ }^{5}$

The interviews were analyzed in Atlas.ti. First, I distinguished all the instances when interviewees made references to wider market processes to explain their opinions or individual strategies. At this moment it became clear that the idea of crisis (events preceding it and effects that it has) is the main organizing point of most of the stories.

\footnotetext{
${ }^{5}$ While English is not necessarily the first language of the Indian interviewees, English generally is viewed as the lingua franca of the consecrated contemporary art world in India. Apart from one artist, who started his career in New Delhi very recently, but quite late, in terms of age, I did not observe anyone having trouble communicating in English. My own difficulty was to adjust to the wide variety of accents.
} 
After that, I looked for the elements of the narrative structure in these descriptions (such as particular temporality of accounts, elements of a plot, heroes, and villains). In the end, I looked for the similarities and differences in the accounts in order to evaluate the coherence of interpretative frameworks in each market.

By this procedure I aimed to observe the "cultural work" (Pugh 2013) done by participants of the two markets. I am not so much interested in the accounts of individual particular practices given by my interviewees, but rather in how they embed them in a more general frame. In this way, I am looking at the narratives about crisis as an example of a particular "cultural schema" that organizes art market participants' perception of their environments, and I zoom into this schema by focusing on its structure. In other words, the aim is "to understand the kinds of work the term "crisis" is or is not doing in the construction of narrative forms" (Roitman 2014, p. 3) and the influence of this work on the dynamics of two markets. With the last step of analysis I am trying to figure out how widespread a particular version of a crisis narrative is, and therefore make a move towards Vaisey's approach to cultural analysis that values the potential of generalizations (Vaisey 2014) (and the claim that albeit constrained by the qualitative interview data, I can still make those generalizations for a tight community of participants of emerging markets). Yet, for me the observation of coherence throughout the market (or the lack of it) is not an end goal, but the point for interpretation of a condition that the market is in.

It is also important to reflect on the interview situation. First, an interviewer invites respondents to a "storytelling situation" (Maines 1993, pp. 21-22). As with any research method, interviewing has its own implications for involved participants (Law et al. 2011). The situation of a research interview is a social performance (Lamont 1992; Alexander 2004) of participants rather than a neutral tool to collect facts and opinions. I follow the ways they present their actions as meaningful in conversation. I focus on the embedded narrative performances (Cunliffe and Coupland 2012) about the art market that respondents construct during the interviews.

Secondly, Maines claims that any speech act "contains at least some elements of narratives" (1993, p. 21). In the situation of an interview, people are provoked to be more explicit and reflexive than in conversations among each other. Respondents need to articulate their assumptions and background knowledge in order to create meaningful discourse. Thus, more elements of a narrative come forth. Through the elaborate narratives about the art market, respondents performed their expert position in the field. This provided rich and culturally thick data for the analysis.

At the same time "narratives do not necessarily describe what is real, but are imaginative constructions of order" (Cunliffe and Coupland 2012). Narratives are multiple and vary according to "situation, audience, individual perspective, and power/authority relations" (Maines 1993, pp. 21-22). Narratives performed during research interviews are in some way inevitably different from the narratives performed in a different situation. Nevertheless, the rigid and objectifying narrative structure demands a certain level of repetition. Presenting events in the form of a story is a natural impulse (White 1980, p. 5) necessary not only for the presentation of them to the listener, but also for a speaker herself in order to make sense of ones actions. If a narrative were to change considerably each time it is performed in a new situation, it would lose its main function of being a sense-making tool. Therefore, I assume that I do not analyze any unusual stories invented just for a 
researcher or outsider. Giving interviews is a typical activity of many art market actors. In fact, as a social scientist, I was often confused with and sometimes treated as a journalist. Articles in the general and professional media published in the period of my fieldwork contain similar narrative elements, and thus support the reliability of the analysis.

\section{Empirical case study: Two versions of crisis narratives}

\section{Background of the two narrative situations}

While direct comparison of the Indian and Russian art markets performance is not the main goal of this article and its empirical section, it still might look like an unlikely couple to bring together in a single article. I argue that these art markets have many similarities that allow claiming that the two cases represent the same type of an "emerging" market, and they have many differences that provide fruitful soil for observing the potential diversity of narrative situations. While non-Euro-American case studies are usually singular or regional, looking at two peripheral markets with very diverse socio-cultural backgrounds may bring unexpected results, since the criteria for comparison are not established yet (unlike in the situations when a new or peripheral case is studied from the perspective derived from the existing knowledge about central and established prototypes) (Herwitz 2001).

The Russian and Indian contemporary art markets are similarly framed as "emerging" or "developing" by professionals and academics (McAndrew 2009, Robertson 2011, Velthuis and Curioni 2015. Even though rare sales of art happened in both countries, the art markets were practically non-existent there before the economic liberalization of late 1980s and early 1990s (see more in McAndrew 2009). Today, the volume of the Russian domestic art market is estimated to be around \$25 million (the latest figures are for the outcome of 2016, from www.ARTInvestment.RU 2017). ${ }^{6}$ The contemporary art sector is considered just a small fraction of the whole art market: experts estimate its size to be around $€ 2.5$ million (InArt 2016). Domestic sales of South Asian art at Indian auctions amounted to $\$ 58$ million in 2016, with contemporary art being only $5 \%$ of it (i.e. around $\$ 2.9$ million) (ArtTactic 2017). ${ }^{7}$

In the meantime, the two young art scenes underwent similar developments, with opening of internationally oriented commercial galleries and auction houses, establishing new art clusters, fairs, magazines, biennales, etc. (see Table 2 for the overview of existing contemporary art infrastructure). The markets are also said to have many similar problems: an underdeveloped infrastructure and legal framework, the relative absence of collectors, professional media or criticism, state support, contemporary art museums, etc. In both countries these problems were systematically raised during the interviews. Yet, while on the surface the similarities are numerous, they are limited due to the significant differences in socio-cultural context in which they occur. Simultaneous

\footnotetext{
${ }^{6}$ This estimate includes domestic auction and private and gallery dealers' sales that include all fine art by artists born in the Russian Empire, Soviet Union, and contemporary Russia.

${ }^{7}$ The estimates for gallery and private sales in India are not available.
} 
Table 2 Institutional infrastructure of the contemporary art markets in the central cities of Russia and India

\begin{tabular}{|c|c|c|}
\hline & New Delhi and Mumbai & Moscow and St. Petersbrg \\
\hline Contemporary art galleries (in 2013) & $\approx 70$ & $\approx 90$ \\
\hline $\begin{array}{l}\text { Contemporary artists (Working with these galleries, } \\
\text { according to their websites) }\end{array}$ & $\approx 2800$ & $\approx 1600$ \\
\hline Art fairs & $1^{\mathrm{a}}$ & $1^{\mathrm{b}}$ \\
\hline Auctions & $3^{c}$ & $1^{\mathrm{d}}$ \\
\hline Governmental museums & $1^{\mathrm{e}}$ & $8^{\mathrm{f}}$ \\
\hline Private museums and exhibition centers & $1^{\mathrm{g}}$ & $8^{\mathrm{h}}$ \\
\hline Private foundations & $1^{\mathrm{i}}$ & $6^{\mathrm{j}}$ \\
\hline Professional print media & $4^{\mathrm{k}}$ & $3^{1}$ \\
\hline
\end{tabular}

There are no official public directories or sales data for art markets in both countries. Therefore, it is hard to provide a quantitative overview of them. The information presented in the table was collected by the author as a preparation for fieldwork from multiple different sources and is often an estimate rather than an precise number

${ }^{a}$ India Art Fair (former India Art Summit), New Delhi, est. in 2008

${ }^{\mathrm{b}}$ Art Moscow, 1996-2013; Cosmoscow, 2010, 2014-2016

${ }^{\text {c }}$ Saffron art, Mumbai, est. in 2000; AstaGuru, Mumbai, est. in 2008; Pundoles, Mumbai, est. in 2011; Osians, Mumbai, 2000-2013; Art Bull, New Delhi, 2012-2014

${ }^{\mathrm{d}}$ Vladey, Moscow, est. in 2013

${ }^{\mathrm{e}}$ National Gallery of Modern Art, New Delhi, contemporary art wing since 2010

${ }^{\mathrm{f}}$ The State Tretyakov Gallery, Moscow, contemporary art wing since 2001; The Moscow Museum of Modern Art ( 5 buildings), est. in 1999; Multimedia Art Museum (former House of Photography), Moscow, rebranded in 2006; The National Center for Contemporary Art, Moscow, est. in 1994; Moscow Museum and Exhibition Association Manege, 6 museums est. between 1989 and 2010; The State Hermitage Museum, St. Petersburg, contemporary art department since 2007; The Russian Museum, St. Petersburg, contemporary art department since end of 1980s; The State Russian Museum and Exhibition Centre ROSPHOTO, est. in 2002

${ }^{\mathrm{g}}$ Kiran Nadar Museum of Art, New Delhi, est. in 2010

${ }^{\mathrm{h}}$ M'ARS Centre for Contemporary Art, Moscow, rebranded in 2015; Garage Museum for Contemporary Art, Moscow, est. in 2008; ART4.RU, Moscow, est. 2007; The Institute of Russian Realist Art, Moscow, est. in 2012; The Winzavod Centre for Contemporary art, Moscow, est. in 2007; Cultural Centre - Loft Project Etagi, St. Petersburg, est. in 2007; The New Museum, St. Petersburg, est. in 2010; Erarta Museum and Galleries of Contemporary Art, St. Petersburg, est. in 2010

${ }^{\mathrm{i}}$ Devi Art Foundation, Gurgaon, est. in 2008

${ }^{j}$ Ekaterina Cultural Foundation, Moscow, est. in 2002; Stella Art Foundation, Moscow, est. in 2003; BREUS Foundation, Moscow, est. in 2007; V-A-C Foundation, Moscow, est. in 2009; Pro Arte, St. Petersburg, est. in 1999; Airis, St. Petersburg, est. in 2008

${ }^{\mathrm{k}}$ Marg, est. 1949; Art India, est. in 1996; Art and Deal, est. in 1998; Take on Art, est. in 2009

${ }^{1}$ Artkhronika, 1999-2013; Khudozhestvenny Zhurnal, est. in 1993; ArtGuide, est. in 2009; The Art Newspaper Russia, est. in 2012

development of the two new markets has become possible in the context of liberalizing national economies, but the background of these transformations is not the same.

The dissolution of the Soviet Union brought not only new market possibilities, but also significant political and social changes that affected daily lives of the majority of the population. Many, including novice art dealers, took this rupture as a possibility to start business from scratch (see more in Komarova and Velthuis 2017). The new government 
released control over private commerce for art (that was previously forbidden) and over legitimate artistic styles (that were previously censored via an elaborate system of official art organizations - see more in Kharchenkova et al. 2015; Yankovskaya and Mitchell 2006). Thus, no commercial gallery existed in Russia until 1988 and unofficial art could only be exhibited underground (Kholmogorova 2014; Slovaeva 2014; Starodubtseva 2014). The emerging market for contemporary art, therefore, to a large extent started as an opposition to existing tastes and social and institutional hierarchies.

Economic transformations of India on the edge of the centuries were sound, but they did not have such a profound effect on artistic production and did not challenge existing social structures. In fact, the oldest of the still functioning private art galleries (Dhoomimal Art Gallery in New Delhi) opened in 1936 and the most celebrated art movement in the current art market—Progressive Artists' Group —was established in 1947 (Brown 2009). Many of the current art market actors are at least the second generation of art connoisseurs from established elite families (see more in Komarova and Velthuis 2017; Poulsen 2012; Joshi 1985). Economic reforms of 1991 opened up the country's economy (Kaushik 1997) and put to an end the long lasting spirit of disavowal of conspicuous consumption (Khaire 2011). As a result, art suddenly became a commodity, an expression of wealth and new modern identity (Brosius 2012). This gave a boost to the newly emerging market without challenging the historically strong stratification system (Vaid 2014).

These historical differences also have an effect on the different intensity of governmental involvement in arts. While post-Soviet Russia released the bans on private commerce and quit the rhetoric of single official art style, the new government has not lost its interest in defining the country's cultural policy. It has redirected quite some infrastructural resources to accommodate contemporary art movements. At times, it still wishes to play a role of a big brother and have a final saying in what is appropriate or not in the field of art (Bernstein 2014). As a result, art market actors still see the state as a natural (sometimes annoying, but sometimes helpful) participant of the art scene. In India, on the other hand, contemporary art is mostly a business of private entrepreneurship and private consumption. The Indian government has limited interest in contemporary visual culture directing its cultural policy and resources on maintaining the national cultural heritage, that is perceived and a crucial element in building the national identity (see, for example, Government of India RFD for Ministry of Culture 2014).

Finally, one reason I find differences in narratives about crisis in the two countries may be related, not to the perceptions of the art market environments, but instead, more generally, to the differences in narrative traditions in both countries. However, I suggest that we can disregard this explanation since scholars have argued that the narrative traditions of the two countries both have similar roots and yet differ a lot. Thus, Halliday (2014 [1933]) argues that all Indo-European folk tales have a common stock of plots: "If a representative collection of folk-tales from any two countries between Iceland and India be examined, a large proportion of the tales will be found to be common to both" (p. 13). Importantly, the similarities that she observes come not only in content, but also in patterns - structures of stories. On the other hand, researchers on Indian narratology have shown examples of Asian narrative tropes that are not characteristic for the Russian ${ }^{8}$ narrative tradition (e.g., there is a

\footnotetext{
${ }^{8}$ We are talking about the ethnic Russian narrative tradition that became dominant in the period of the Russian Empire and spread further with standardized mass education during the Soviet period. There are ethnic minorities in Russia with distinctive narrative traditions.
} 
tendency for serialization, i.e., creating a never-ending series of episodes not necessarily temporarily sequenced - see more in Jindal 2016; Ayyappa Panicker 2003), that is closer to European examples favoring a clear temporal dimension over the spatial one. ${ }^{9}$ Disregarding which position we take, several points are to be made. First, even if the Indian narrative tradition is originally different from the Western one (that is a source of theoretical arguments about the narrative structure), it was considerably altered during the colonial period (Goebel and Schabio 2013). Secondly, with cultural globalization, proliferation of international media, global dominance of Hollywood movies, the narrative structures all over the world become more homogeneous (Olson 1999). Finally, the developed analytical framework is grounded in a structural approach to narrative analysis (Alexander and Smith 2001) that looks for universal elements of narrative grammar, such as structural roles of heroes and antiheroes or persistent emplotment of selected events, but does not deny a possibility of context specific narrative tropes within this grammar.

\section{India: Boom and crisis rhetoric}

In India, people with diverse social backgrounds, occupying different social positions built a surprisingly homogeneous image of the art market's development. Neither performance in the art market nor international and local recognition had an impact on the general narrative structure of the stories I recurrently heard during fieldwork. The narrative about the Indian art market crisis had a clear sequenced structure, and a plot comprising the references to the glory of the past, a contamination point, a critical external rupture that allows for later moral restoration, and positive evaluation of the market's prospects. Different elements of the same sort appear across interviews and rarely contradict each other. All my respondents placed the crisis in the past. In particular, they used the term "crisis" to describe the precipitous drop of auction prices in 2008-2009. "Crisis" was something that happened, but did not last. The period after the crisis was seen as a slow but steady improvement of the market in times of economic recession. The global economic crisis is presented as an external rupture that unexpectedly influenced the local art market, but artists and art dealers generally share an idea that the crisis in the art market "should have happened at some point" anyway $(\mathrm{I} 27 \mathrm{dg})^{10}$ because the market boom (preceding the crisis) "was very artificial" (I12_da). Thus respondents argue that major problems of the Indian art market date back to "when suddenly this so-called boom came." Rhetorically a story about the "crisis" always starts with references to the "boom" accompanied by what Sooudi (2015) describes as a "moral crisis" of the Indian art world. Thus, a narrative about crisis encompasses a lot of moral claims about the Indian art market via references to improper attitudes and behaviors dominating the art world of this period. But let us look in more detail at the main structural elements of this narrative.

\footnotetext{
9 The dominant Russian narrative tradition is usually not seen as different from the European one. For example, the classical analysis of Russian tales developed by the Russian scholar V. Propp is generally taken as a forerunner of the structural approach to narrative analysis (Dundes 1997).

${ }^{10}$ Here and further in the text I use codes instead of the names of my interviewees. The first part indicates the number of an interviewee in the overall database. The second part indicates the city ( $\mathrm{d}$ - for New Delhi, mu - for Mumbai, sfor Saint Petersburg, mo - for Moscow) and the position of the interviewee (a - for an artist, $\mathrm{g}$ - for a gallery).
} 
Boom, "moral crisis," and the contamination power of money

The boom is said to have started between 2002 and 2005. The Christie's auction in New York on September 19, 2002 is often named as the symbolic mark of its beginning (I32_dg). That is when then the triptych "Celebration" by Tyeb Mehta was sold for more than $\$ 300,000$. It had remained the most expensive piece of contemporary art from India sold in a public auction ${ }^{11}$ for about three years, when the work of the same artist "Mahishasura" hit a new record of $\$ 1.58$ million on September 21, $2005^{12}$ (Christie's auction in New York). Consequently, Tyeb Mehta has become one of the symbols of the boom. Art market participants perceive the rise of prices for his works as dramatic and often greatly exaggerate it by adding several extra zeroes in their stories (I13_da).

This extreme escalation in prices is presented as a key characteristic of the "boom." The words that were used to describe this period are "ridiculous," "crazy," "scary," "tough." A successful Delhi-based artist, with an impressive record of collaborations with galleries across the country recalled:

It was very interesting time, but also very very scary, because an artist like me, I could not increase my prices [with no reason].... So it was a very very tough period to keep our morale.... For us I think it was a great change.

To explain the change, she proceeded with a story that reveals the shift of attitudes in the art world:

I was giving my resume to one of the shows and it was very funny and they said: [Artist's name], you've been painting for 30 years, but can I write 20 instead? ... I said: Why, I've been painting for so long! She said: But you actually started selling [20 years ago]. And I said: Okay you are talking about the time when I became $a$ seller. It is not about when I became an artist, ... so it was a very sad moment! (I30_da).

According to many participants in the art market, people who are interested in the commercial side of the business are not interested in art itself. Such active "denigation" of economic interests (Bourdieu 1993) fits a contamination model according to which art and money represent two hostile worlds (Zelizer 2000; see more about it in Velthuis 2003). It means that becoming an actual market (during the "boom") with fast growing demand and supply supposedly damaged the art world. Another established artist from New Delhi explained that period:

Then suddenly this so called boom came ... because what happened was, it brought in investors. And the actual collectors shrunk. Because the prices went [too] high. Because these investors they would buy 20-40 paintings and then they would increase

\footnotetext{
11 "Artist for all times" in The Hindu (Online edition), Wednesday, Jan 22, 2003 [http://hindu. com/thehindu/mp/2003/01/22/stories/2003012200460100.htm]; The Christie's lot —Celebration (1995) by Tyeb Mehta. [http://www.christies.com/lotFinder/lot_details.aspx?intObjectID=3970180].

12 The Christie's lot-Mahisasura (1997) by Tyeb Mehta. [http://www.christies.com/presscenter/pdf/09232005 /1552_ind_tt_092305.pdf].
} 
the prices artificially in the auctions. And you see a lot of auctions come [in].... And in the auctions the prices went the high way absolutely because the investors wanted to make money. And there was no other business or no other shares or anything which could command such a fantastic profit. It was 20 times, 30 times what you put in. And they didn't even know the artist they were buying and they didn't know anything about art. In that sense it was very bad for the art (I12_da).

The sudden inflow of money in the art market attracted the "wrong" people to the industry simultaneously pushing out the "right" ones, because the prices went beyond the reach of "real" art lovers. With an emotion of despair a rather young but successful dealer, who opened her gallery in Delhi when the boom was already over, claimed that during this "nasty" period "everybody was an investor, everybody." "Nobody was a collector, a collector became an art dealer soon" with an interest of making quick money on selling their collection (I20_dg).

Thus, the main villains of this dramatic narrative are the numerous newcomers to the Indian art scene-investors. Furthermore, money has seemingly spoiled many other participants of the art world. Artists (even the most honorable of them) also have changed their objectives and agenda. For example, according to one of the longest operating art dealers in the country, who claims not to fall for the market logic and therefore operated at a loss for the most part thirteen years, artists suddenly started arguing for better prices and destroying long friendships; moreover they significantly increased their production speeds:

I knew that this would create a bubble and that was dangerous not only for the commercial side of the art but for the aesthetic side of the art. The art, the artists started producing instead of one work a month they started producing 30 works a month. That's bad for the quality, that's bad for everybody (I37_dg).

Rhetorically the blame for the boom and for the following crisis is always put on some third persons (investors, artists, auction houses), as the following quote exemplifies (emphasis added):

I was in London years back when the boom time started, all [hedge] funds were opening left, right and center. In India there were five people who started a fund in Bombay, I know of some in Delhi also. They would start a small fund and then they would pull in money and then they would buy [art]works. So now they wanted to exit with the fall-falling of the market, but they didn't know what to do. Now, they don't buy, they all disappeared. They must have distributed the works amongst themselves (I27_dg).

The villains of the art market are usually abstract; they have no names with the only exception of the Bodhi Art Gallery, ${ }^{13}$ which is often mentioned as a key actor of the boom time and the symbol of all the evils that have happened. Closed right at the moment when the art market bubble burst, it is recalled as an "extremely hyper aggressive commercialist"

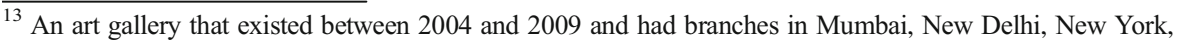
Singapore, and Berlin.
} 
(I57_mug) actor that contaminated many others with the spirit of investment, short-term planning, and large-scale projects. But Bodhi gallery has closed and all other anonymous villains of the story seem to be nowhere found nowadays - dubious galleries have closed, greedy artists are forgotten, investors and speculators have vanished-" "they are [shut] down, nowhere around on the scene now" (I27_dg).

Thus the narrators take an observant position in the story about the crisis and disassociate themselves from events of the boom period. These are the stories of winners who survived the crisis; their narrators are in a privileged position to interpret the situation in their terms. Thus, the "I's" and "we's" of the narrative are the ones who did not fall for the urge of money. Instead, they supposedly "warned," did not inflate the prices without reason, turned down dubious business suggestions that promised big and quick money, knew from the very beginning that it was all wrong and just a bubble, etc. This rhetorical distancing shows that such behavior is considered morally improper today. As an established art dealer from Delhi explains, now they are the ones who are rebuilding the market, when the villains have vanished:

And that's why people like us get frustrated and get irritated with that whole thing of buying and how, you know, we should be in business now, or how we should improve it, or how we can't really contribute more (I27_dg).

While art market participants perceive the pricing crisis as something that came from the outside - "the big correction to the market in 2008" - is always linked to the "boom," or the moral crisis of the market, which embodies all the internal problems of the art world of the time. As art market participants argue, the link between the "moral" and "economic" crises of the Indian art market is contingent - "if the Western markets didn't fall the bubble should have burst at some point anyway" (I36_da). Nevertheless, this link is still very strong as the "normal" pre-crisis state of the market is to be found before the boom. The present state of the art market is compared with the pre-boom "dream time" of the art world.

\section{"dream time" of the past and the present of new beginnings}

Art market actors consistently contrast the crisis times to 1990 s and preceding years, which are presented as a more normal functioning of the art market. Both artists and commercial art dealers recall that time with warm feelings, when only "enthusiasts" were in the business, artists were getting "great support." A Delhi artist with over thirty years of experience in the local art field shared:

Indian market had not opened up but it was the most exiting period - there was no hurry to reach anywhere, there was no art market; there was nothing that I was looking forward to as a market or as an audience (I30_da).

Similarly, an influential Delhi dealer started an art gallery in the late 1980s because he "loved the romance involved with art." To explain the peculiarity of these early years in the art world he explained about prices: 
At that time we never spoke about prices. Prices were not an issue.... I would join [artists] and it was all about art and it was all about aesthetics... So I call that a honeymoon period for the gallery, and once we "got married" in 2002-2003 to this money (I37_dg).

This period is characterized by the slow pace of business, rare sales as well as the relative independence of India from the world financial turbulences and steady economic growth. Surprisingly, the absence of the market seems to be the time that is valued most positively in the narrative of the market. In comparison to this "dream time," the time "after the crisis" that is still lasting in the narrative is described very similarly. Art market participants can easily accept that there is no market nowadays or that commerce has almost vanished and still paint the positive picture of the new beginnings. For instance, an internationally recognized Mumbai art dealer cheerfully informs me that there are "like zero buyers for Indian art. So we have to start all over again" (I57_mug). Another art dealer from Delhi adds to this that artists finally have time to "think and reflect" about their artistic practice again (I27_dg) and many artists note that some old collectors, who exited the market during the boom, "return" nowadays (I12_da; I36_da). The Indian art market has "turned to the new cycle" and is again "at the beginnings of a trend" (I56_mug).

While the story of the Indian art market narratively seems to return it to the very beginning state, some things have changed, which allows me to consider this narrative complete in White (1980). The boom and later crisis have taught the market some "lessons": the "art market [is] becoming more mature, the art scene [is] becoming more mature" (I27_dg). The new heroes of the narrative have emerged to save the market from the crisis - "a new generation" of young collectors, who "are buying from their heart and not driven by the monetary value of what they are buying or the investment value of it" (I18_dg). There is a widely shared belief in this group of people:

Because this younger generation, they're [in their] thirties and forties, and awareness ... the thing is that awareness has become I would say a thousand times more than [just] the buying capacity (I27_dg).

These new collectors embody characteristics that are the opposite of those of the villains who are blamed for ruining the market: they are interested in art and not money, they come to see art at exhibitions, and they educate themselves, "their tastes are growing,"- - they are supposed to bring the market to the bright future. Thus, a young Delhi-based second-generation art dealer reconstructs the transition of the market through these periods in a few sentences:

[The market] is more stable, because of what happened in the boom, there was a lot of not so good art that was piggy backing on the great art and everything was doing well, everything was selling.... Also because collectors in India that time [before the boom], it was an innocent market, they were naïve, there wasn't that much exposure, but now collectors are so much more aware, they're educated, there are two private museums in Delhi, so all of those things that actually contributed to making collectors more aware and more careful with the choices that they make (I34_dg). 
In fact, this capacity to tell the short and condensed history of the Indian art market indicates that this experience has been successfully historicized-put into a narrative form and performed even by actors who were not personally involved.

The narrative about the Indian art market revolves around facing and coping with moral and economic challenges. The rigid structure of this narrative, reproduced in multiple individual stories, performs a certain work in the market. The temporality of the narrative produces a perspective for assessing the market development and for building expectations of the future. In the case of India these expectations are invariably positive, disregarding the generally acknowledged shortage of sales. This is made possible by symbolic linking of the current low state of a market to the "dream time" of the Indian art scene, when everything was "still fine." Thus, low prices and volumes of sales are justified by attaching positive moral judgments to behaviors that do not prioritize commerce. Some art dealers finish the story with an overly optimistic prognosis expecting that the Indian art market will reach the size of the US market within the next five years (I18_dg). While such promises are not likely to come true, they follow the logic of the narrative that creates what Beckert calls enjoyment by anticipation (2013).

The experience of crisis expressed in a narrative form has a bonding effect for the Indian art world. According to the narrative performed by art market participants, the crisis has purified the market. It rhetorically suggests that only the actors who share similar values are still active in the market. Thus, by employing this narrative (even without being present in the market over the course of its span), actors send a message to the audience that they are not those "dubious investors" who are in the market with a short term interest, you can trust them, and poor economic outcomes are only the proof of it - art for art's sake is their main goal.

The narrative of crisis has a productive function in the Indian art market - it creates cohesion and produces a perspective for the future, which is necessary for the market to operate. A consistent model of market development allows collaboration between the art dealers and reduces uncertainty for potential buyers - new young collectors that everybody wishes to attract.

\section{Multiple Russian art market crises}

Art market participants in Russia also refer to some crisis as explaining the way the market develops. However, when Indian market actors place the crisis in the past, their Russian colleagues are convinced that the market is in crisis at the moment. As a result, the stories about the crisis of the art market in Russia lack a temporal dimension. It is hard to find any time points in the stories. Sometimes interviewees mention 2007-2008 as a critical moment when art market activity changed; however, most often the discussion of the crisis is simply formulated in the present.

In addition to the lack of temporality the stories about art market crises in Russia lack a clear plot. They are much closer to what Boje (2001) calls antenarratives since several fragmented stories about the crisis fight for public recognition. Being less structured two versions of the possible narratives are nevertheless analytically distinctive, even though their use by various art market actors is inconsistent. While some actors take only one standpoint, others often contradict themselves and create a mix of the two. 
The oldest players in the art market - art dealers, who have actively participated in the art world at least since the early 1990s, develop the first understanding of a crisis in the Russian art market. It focuses on external problems (the political and social situation in the country) and contextual factors (general tastes in art, museum policies, etc.) that do not let the market develop. These dealers are by far the most established players in the market. Younger actors of the market, who entered it in the early 2000s, actively blame the oldest players in the field in the current crisis of the market and thus develop the second version of a narrative about the art market crisis in Russia. It mainly focuses on the internal, structural problems of the market (pricing principles, regulations in the market, relationships among art market actors, etc.). Nevertheless, while advocating for this understanding of the crisis they rather often also use arguments of their opponents.

The depth of the contradiction was exposed in April-May 2012, when three out of the four oldest and most famous contemporary art galleries in Moscow simultaneously announced their closure (Guelman Gallery, Aidan Gallery and XL Gallery) and organized a press conference at the Winzavod Centre for Contemporary Art to discuss the reasons of this decision. What was really going on with the galleries was unclear, ${ }^{14}$ but the event caused many debates about the state of the contemporary art market in Russia and revealed the two contradicting positions with regard to this question. A year later, the debates about the crisis state of the Russian art market have not ceased. The global financial crisis of 2008, being an external shock for the art world, was only loosely related to the problems of the Russian art market that some participants of the market called a "collapse."

\section{External crisis of the art market and a unique model of development}

The first story about the art market crisis was most prominently emphasized by the art dealers who initiated the press conference and supported by artists who were active in the field since the emergence of the Russian art market in late 1980s or even earlier. The opening statement of one of the art dealers at the press conference in April 2012 reflects the general set up:

The situation is critical; there is no market for contemporary art in Russia anymore. And there are no signs it has a chance to come back (I139_mog).

Instead of explaining what it means or what was there before the market "collapsed," the story focuses on the reasons for the poor state of the art market, listing the (seemingly endless) problems caused by the socio-political situation in the country and blaming various relevant external institutions for the art market functioning. This way of talking about crisis not only lacks a temporal dimension and structured plot, but also has neither clearly defined villains nor heroes who can push the art market out of the crisis.

Among numerous problems, two more general independent crises are most often considered to have had a major impact on the Russian art market: the global economic crisis of 2008 and the political crisis in the country, which is said to have started with a new election cycle in the autumn of 2011 and consequent mass protests. ${ }^{15}$ Two

\footnotetext{
${ }^{14}$ Only one gallery has officially stopped selling art and people in the art community still say that it is possible to buy art there.

${ }^{15}$ See more about the political crisis of 2011-2012 in Russia in Monaghan 2012; Yanitsky 2013.
} 
Moscow art dealers had very charged views on the negative effects that the current political situation was having on the art market, so for about an hour during the interview we were talking only about this (I140\&I141_mog). Another Moscow art dealer explained the impact more directly, in his view old collectors of contemporary art "have flown away [from the country], and the new rich - the bureaucrats - are not willing to show off their money, thus they will not collect art" (I89_mog). He went on to give some figures:

Around 80 percent of all the collectors of contemporary art have left the country. ... The collapse of the art market is directly related to the increased level of corruption and general atmosphere (I89_mog).

The art dealer makes the point that the general atmosphere is unfavorable to the type of contemporary art that internationally oriented art galleries work with. As a result, there is no development of the wider art world infrastructure that is necessary to support a stable market. Artists and dealers in Russia can list the contextual elements that are lacking or malfunctioning almost endlessly: art critics do not write about exhibitions, museums are not interested in contemporary art, production services are very expensive, their quality is very low, etc.

While the pioneers of the Russian art market consider the type of art they are working with to be international, the problems of the market are presented as specific for Russia. Thus, the art market in Russia is said to be developing in its own way, different from the rest of the world. Art dealers claim that "the Western gallery model is not working here" (I139_mog), so adoption of the international practices of art commerce cannot help the Russian art market. In particular, there is a widely shared view that the "sustainability of a commercial gallery is impossible in Russia" (I86_mog).

Therefore, to overcome the crisis, art dealers claim to search for some "unique" mechanisms of external support. As an example, the commercial galleries that initiated the press conference decided to switch to or refocus on various non-commercial activities (such as curating non-commercial shows, artistic education or support of regional artists). They explained that a non-commercial status allows art dealers to "ask for sponsorship" from private or even governmental organizations for their projects, while requesting such support as a commercial organization is illegitimate or even legally impossible. The strategy of coping with the crisis, as understood in this story, is to attract an external inflow of money.

The art community generally knows that contemporary art galleries in Russia had other sources of income that supported their existence from the very beginning. ${ }^{16}$ Several of my interviewees claimed in informal conversations that there is still not a single gallery that is sustainable from commercial sales of art alone. Thus, external sponsorship of the art market can indeed be perceived as a "normal" way of functioning. The experienced lack of such support is what these art dealers consider a crisis.

This understanding of a crisis is shared and actively elaborated by an easily identified group of actors. Yet, it is not presented in a structured narrative form. This version of a story about the crisis of the Russian art market has only some elements of a

\footnotetext{
${ }^{16}$ For example, one art dealer has a political background, another started an art gallery in order to build a corporate collection for his bank. Often a family business can support the running of a gallery (e.g., jewelry).
} 
narrative. For example, there is a distinction between the pre-crisis state and a current crisis of the market. Only some general ideas about the causes of the crisis are formulated, the villain is rather abstract, and normative claims are vague. Although art dealers observe a negative trend, there is no clear sequence of events that create it, no plot has been developed, and no (possible) ending of the crisis is identified.

\section{Internal crisis of the art market}

Younger plays in the field present a different view. Their story is characterized by a relatively clear villain. A range of art market actors elaborately blame the oldest art dealers, who established the market in the early 1990s, for all the current problems. In contrast with the Indian case, art market participants very often mention specific names or use generalized names for these people such as "these oldest galleries," or the "curatorial dictatorship of the art dealers in the 90s" (I99_mog). While these art dealers are recognized as "fathers" of the market, they are at the same time blamed for not being able to build a proper market, for their attitude towards its functioning today, and for their approach to art commerce. Thus, they are blamed for the deep structural problems of the art market. Within this version, the crisis is apparently rooted in choices made by the pioneers of the market early on. Therefore, there is no clear beginning of the crisis in this story and it is not clear if the Russian art market was ever in a non-crisis state.

The most elaborate part of this narrative is a discussion of the reasons for the crisis in relation to the villains who caused it. According to these younger players, one of the main "faults" of these villain art dealers is their elitist approach. The art community is blamed for overlooking some talented artists, who could be successful, but do not fit their agenda. It is depicted as a small closed art fraternity ("tusovka") with "Napoleonic habits, meaning 'I am the king' and everybody else are servants." The aesthetic, intellectual, and social closure of the group prevents the market from developing. Whereas the market needs "new blood," it is "dying out" instead (I96_mog). Art dealers who produce this type of story claim that the supply side of the market should be interested in what the audience is looking for and can appreciate.

Such an elitist approach is often rhetorically linked to another problem of the market within this story: unrealistically high prices. A young art dealer, who intentionally decided to stay away from the Moscow art cluster, explained that these art dealers simply will not work with low prices, thinking it is below their esteem:

As we all know, some galleries just didn't consider selling art below a certain sum [of money], because [for them] it is too petty and strange. But then there were cases that after a while a work went to an auction and was sold five times cheaper. (I100_mog)

This talk about unjustified prices is very common in the art community: the prices are said to indicate the status of the art dealer rather than the artist. Hence, they are often too high, especially for young artists. The oldest art dealers are blamed for their unprofessional and speculative approach to pricing. The price is even said to be determined by an assessment of the appearance of a person that enters a gallery.

Multiple instances of what art market participants describe as misbehavior are so outrageous mainly because the accused art dealers supposedly regard these practices as norms. "Newbies" in the art market are "shocked" when they hear 
that all the problems and lack of regulation that they spot are taken for granted and advocated as a "special" way of developing the Russian art market (I101_mog). Thus, the founding fathers of the Russian contemporary art market are convicted of supporting its current malfunctioning. A successful young artist, who decided to build his career without gallery support, explains that:

All this [questionable] system was naturally built in the 90s and keeps working in an automatic mode. Apart from new galleries, everything else is the business of the $90 \mathrm{~s}^{17}$ (I103_moa).

Artists and art dealers who narrate this story of the market crisis are often observably angry and pull no punches. They claim that the crisis happened because the oldest players in the field do not really care about the market in general and instead "build their own careers," "wish to make big money," "work only for their own interests." The announced closure of the three big galleries and the way they explained their decision in public media is conceived as "whining," unprofessional behavior, and even as betrayal of the industry. A Moscow art dealer complains about the performative effect that the press conference had:

This April so-called closure of the galleries. Very strange. It was a great PR event for them, of course - tell everybody and everywhere about them.... But, you know, when such an ominous front page comes out with a title "I gave birth to the art market and I am the one who will kill it"... first of all, this is just not nice ... masses read this. And all the time it is just critique, critique of artists, critique of everybody around (I100_mog).

The claims that there is no art market in Russia anymore are said to have shadowed the galleries that did not close and scared off potential buyers.

This story of the crisis implies that the rules of the market prevailing in Russia were initially wrong: the market operated in the grey zone, prices were not clearly established, etc. Therefore, coping with the crisis requires "repairing the art market" by building it according to other, new rules. While the actors performing this story make moral judgments, the source of normativity cannot be found in the past - they need to look for other exemplary models of running their businesses. Art dealers and young artists advocate for clarity and openness of information and take their limited European experiences as an example. The normativity in this story comes from outside the Russian art market. To succeed and cope with the crisis, art market participants are supposed to adopt the "Western" approach to art commerce that they can learn about either by personal experience of participation in the international art market (via art fairs, collaboration projects, or branches in other countries) or, in case of this young Moscow art dealer, simply from books:

\footnotetext{
${ }^{17}$ The reference to the business of the 1990s has negative connotations in Russia as this period is generally regarded as the "wild" time of legally dubious economic practices and short term planning.
} 
We try to inculcate very basic things that you can find in the book "How galleries operate." Everything is written there. So if anybody forgets something ... you shouldn't really [forget] (I101_mog).

This story of the art market crisis has a clear villain but no temporal dimension or sequenced structure. The normativity is searched from outside the market. Therefore the plotting of such story is problematic. Nevertheless, this understanding of crisis stands in clear opposition to the one developed by the pioneers of the art market. While the first story about the art market, in which the crisis comes from the outside, aims at defending the existing rules in the market, the second one - that is stressing the internal problems - is contesting them. Art dealers that produce this type of story demand change.

While two understandings of the market crisis are in opposition to each other and thus can be analytically distinguished, two parties are not equally consistent in following them. The oldest players in the field are rather consistent with their emphasis on the external problems that do not let the market develop. Younger actors, who are often very negative about the behavior of particular art dealers and emphasize internal malfunctioning, on the contrary, easily switch to discussing the negative environment they have to operate in and can endlessly list the same external problems, which makes their own perspective less convincing.

A clear example is the opinion about contemporary art and its public perception. On the one hand, the younger actors blame the pioneers of the market for a very narrow and specific understanding of art that they impose on the audience. This type of art is sometimes called "filth," "shit," "ugly," "repulsive," and rather often "incomprehensible." Since these are the most well-known art dealers in Russia, they get most of publicity and they shape the public opinion about contemporary art in the country. An art dealer operating from a gallery space in the famous Moscow art cluster, where all the oldest galleries are located, says that

normally people come [to the gallery] with a big dread. Because for most people contemporary art is something at least incomprehensible, and sometimes even scary or repulsive. There are some provocations, there is some dirt, something horrible, unaesthetic, etc. (I99_mog).

He believes that the art he works with is more open for audience and more aesthetically pleasing. On the other hand, in another part of the interview the same art dealer can start blaming the increasingly "obscurantist" atmosphere of the Russian society and claim that the majority of the Russian population does not understand contemporary art. Art dealers then explain that in the general media contemporary art is often contrasted with "authentic" traditional values of Russia and emphasize that this opposition is promoted by governmental institutions (falling on the logic of the external factors causing the crisis in the market).

Similarly, young artists and art dealers sometimes start talking about the peculiarity of the Russian art market and its development not long after arguing that it is in no way different from the rest of the world. As a result, a narration is even less structured and has fewer chances to form a complete narrative. 


\section{Symbolic struggle over the dominant crisis narrative}

These stories represent two conflicting positions in the field of the Russian art commerce and can be explained from the perspective of a market as a field. This conflict represents a symbolic struggle over the dominant interpretative frameworks for the Russian contemporary art market (Fligstein 2002; Bourdieu 1989). While the oldest art dealers of Moscow have built the art market on the basis of available resources and created norms prevailing in the market, the others entered it when it was already set up in a certain way. Thus, older art dealers identify external reasons for the current crisis in order to defend their position and existing market set-up. At the same time, younger galleries demand recognition in the field and do it via constructing an alternative narrative. This narrative does two things: first, it explicitly identifies dominating galleries as the villain of the market; second, it suggests an alternative source of normativity from outside the market and claims that art dealers know the solution to the current problems and therefore can lead the market out of its crisis. The rupture in the market routine exposed by the performed event of the once-powerful galleries' "closure" has opened a possibility to activate this alternative interpretation and question the existing hierarchy. Thus, it gave others an opportunity to claim their right to reconsider existing norms. It explains why the group of art dealers performed an active narrative work by enthusiastic participation in the discussion of the closure of the older galleries and publishing a lot on the topic of crisis in the media.

The stories of the art market crisis performed in Russia are not helping in the consolidation of the field. In their efforts to privilege their own interpretation of the market crisis actors produce polyphony and send mixed signals to the audience. Both of the stories lack some crucial elements of a narrative and, as a result, their performative power. A temporal perspective is important for reflecting market development and producing expectations about its future. Historicizing of the Russian art market apparently has not (yet) happened within the community. There is no reflection about the market as a whole and no shared history as one of the parties denies the legacy of the other. Moreover, there are no expectations for a stable future unless one of the perspectives "wins." In other words, there is no complete narrative and no (happy or otherwise) ending to the market crisis.

Further elaboration of any variant of a crisis story could allow clearer strategies of action and interpretations from the perspective of the audience. Thus, several prominent Moscow art institutions and market actors that defend a view about the external origin of the crisis have started a project aimed at understanding the processes of the 1990s via large-scale exhibitions and elaborate catalogues (Selina and Obukhova 2013). The early 1990s are formulated as a possible "dream time" for the art market narrative. However, the effect from these undertakings on the art market is yet to be observed.

\section{Conclusions}

The global financial crisis of 2008 is frequently tied to crises in other fields, often by imputing a direct causal connection. Existing research has shown, however, that the effect of this crisis on national economies varied due to specific cultural environments (Campbell and Hall 2015). More specifically, context-specific collective normative ideas about the economy have influenced the public framing and perception of the 
crisis and, as a result, the strategies of dealing with it Lindstrom (2015). Therefore, crises in national economies and specific markets that followed the financial crunch naturally have their own dynamics (for art markets, see Velthuis and Curioni 2015. Focusing on the case of art markets, the empirical part of this article can be seen as an example of a close analysis of a market-specific crisis dynamics with broader relevance. I believe, for example, that the evolution of the financial crisis around the world can be understood better if we refocus our attention on meaning-making processes that frame it within distinguishable cultural domains (be it product-specific markets or national economies, in general).

The interpretative approach proposed in this article looks at the phenomenon of a market crisis via the analysis of narratives performed by market actors themselves. While the crisis rhetoric was an organizing idea that explained the market development in two countries, the analysis has shown that, rather than being a major concern, the global financial crisis has become an occasion to reflect on the more crucial problems of the two countries' art markets.

Indian art market actors have reinterpreted the global burst of the economic bubble in a positive vein - as a remedy for the "moral crisis" (Sooudi 2015) that the art market got into due to the influx of investment activities treating art as any other financial asset. This narrative provides currently operating art market actors with moral justification for their activities, despite weak economic outcomes, presents them as trustworthy for market consumers, and reaffirms the status quo norms of the market.

In Russia, the narratives about the art market crisis are more blurred. Different groups of actors develop two competing views. In the first story about the market crisis, which defends the current state of affairs, the economic recession is just one of the external forces that have a negative effect on the art market, along with political processes unfavorable to contemporary art and its conspicuous consumption. The second version of the crisis story does not focus on the financial meltdown at all and instead blames the key actors of the industry in market malfunctioning. For the proponents of this story, the economic turbulences were rather an opportunity to bring up their dissatisfaction about the prevailing market norms and question the existing hierarchies.

In the case of the two art markets in question, the atmosphere of crisis and coping with it was an overarching idea that dominated the narratives about market development. Nevertheless, different markets can "narrativize" other aspects of their functioning. The main contribution of this article is the development of a narrative approach to the study of markets that is aimed at a broader scope of application. Therefore, the analysis of the two cases is an illustration of how narrative sociology can approach markets in order to understand their dynamics and development.

The observed differences in narratives about the Russian art market crisis and interrelationship between them open up social dynamics otherwise hard to grasp. Thus, people from the same social circle produce two conflicting stories of the Russian art market crisis. "Rival" art dealers often rent spaces at the same art cluster and can work with the same artists. The symbolic confrontation between them is revealed only in professional communication. The absence of a shared narrative in Russia reflects the existing competition for domination in the contemporary art market. The polyphony of voices and perspectives makes the stories about the Russian art market fragmented. They lack a clearly defined plot and temporal dimension. This does not allow actors to 
create rational expectations of the future and, therefore, leaves the market highly uncertain.

Shared and structurally elaborate narrative, observed in the Indian case, is possible in the situation of rather indisputable authority and legitimate interpretations accepted by a majority of players in the field (even those who suffer from them). A universally shared narrative of the Indian art market does not necessarily mean complete peace in the social circles of the Indian art world. As art markets participants mention, the most prominent art dealers of Delhi "cannot stay in the same room for long" (I38_dg). Nevertheless, their shared narrative suggests that none of the art market actors contests existing hierarchies and rules. The Indian market aims at projecting stability as if art market reputations are reproduced "naturally." Art market actors operate in a similar meaningful framework, which allows for cooperative action. Definitions of villains and heroes allow moral justifications of activities. The temporal dimension of the narrative creates projections for the future that can serve as a source of certainty and create stability in the market. A narrative of the market does not only convey meanings among art market participants. It becomes a source of cohesion that makes economic action possible, alongside institutional structures and long-term social relations.

The work that performed narratives do in the two markets are clearly different. These differences can be interpreted with the reference to broader cultural contexts of the narrative situations. In India the contemporary art market is seen as a continuation of earlier developments and rests in pre-existing social hierarchies. Thus, art dealers of the "new money"-usually wives of newly rich entrepreneurs dealing in, for example, real estate-often are distanced from the consecrated top of the art market not only socially, but also geographically (with their galleries located outside of famous art clusters). Nevertheless, they also perform the same narrative, not questioning the existing market layout. In Russia, the contemporary art market is a clearly post-Soviet project that started up by defying exiting rules and hierarchies and at the same time denying the possibility of any long-term culturally and institutionally rooted legitimacy. As a result, all the norms had to be established from scratch and were (and apparently still are) opened to contestation. This persistent questioning and contestation may also explain why the crisis framework is so appealing in this context. Thus, Shevchenko (2008) develops a concept of "permanent crisis" and argues for the totality of the crisis framework in the post-soviet Russian society.

This article proceeds from the strong cultural sociological claim that a narrative acts on itself (Alexander 2011). Alexander argues that a market is a narrative, suggesting that agencies of the actors in the market are shaped according to the narrative that the market performs. In accordance with Alexander's stand that the cultural dimension of the market shapes the rationality of the market and guides economic action, we have to study it in detail as analytically separate from other dimensions of economic exchange. Having said that, Alexander's approach suggests that any market has a narrative (2011) or a few narratives are in competition (2002). Yet, it overlooks the fact that a narrative has to be produced, as experiences "do not offer themselves as stories" and their narrativization does not happen automatically (White 1980 , p. 8). Therefore the context of its production deserves attention alongside the analysis of its structure and effects on actions. The analytical framework developed in this article aims to pay attention to both. 
In order not to imply too much coherence, it looks at several "others" of a narrative, such as a narrating discourse that lacks capacity to "narrativize" events (White 1980) or an "antenarrative" (Boje 2001). The latter concept suggests that to interpret plurivocality and intertextuality of stories in a market the conditions of their production should be taken into consideration (such as time and place, intentions of storytellers, or their political stands). The framework employs the tools of narrative analysis, but I suggest that any empirical case is positioned somewhere on a continuum between a coherent and structured narrative and nonlinear and inherently incomplete antenarrative, and the framework can be seen as a bridge between the approaches that study markets as fields (Fligstein 2002) and those that focus on markets as cultures (Zelizer 2010).

Acknowledgments I want to thank Olav Velthuis for the elaborate discussions of multiple versions of this article. The Theory and Society Editors and reviewers provided valuable feedback. Finally, the members of the Culture Club in the University of Amsterdam Sociology Department were very helpful in shaping this articles in its early stage. Earlier versions of this article were presented at the 2014 Spring Conference of the Yale Center for Cultural Sociology and at the 2013 annual conference of the European Sociological Association. The work was supported by the Netherlands Organization for Scientific Research (NWO) [452-10-009].

Open Access This article is distributed under the terms of the Creative Commons Attribution 4.0 International License (http://creativecommons.org/licenses/by/4.0/), which permits unrestricted use, distribution, and reproduction in any medium, provided you give appropriate credit to the original author(s) and the source, provide a link to the Creative Commons license, and indicate if changes were made.

\section{References}

Abolafia, M. Y. (1998). Markets as cultures: An ethnographic approach. In M. Callon (Ed.), The Laws of the markets (pp. 69-85). Oxford: Blackwell Publishers.

Abolafia, M. Y. (2010). Narrative construction as Sensemaking. How a central Bank thinks. Organization Studies, 31(3), 349-368.

Ahrne, G., Aspers, P., \& Brunsson, N. (2015). The Organization of Markets. Organization Studies, 36(1), 7-27.

Alexander, J. C. (2002). On the social construction of moral universals. The 'Holocaust' from war crime to trauma Drama. European Journal of Social Theory, 5(1), 5-85.

Alexander, J. C. (2004). Cultural pragmatics: Social performance between ritual and strategy. Sociological Theory, 22(4), 527-573.

Alexander, J. C. (2011). Market as narrative and character. Journal of Cultural Economy, 4(4), 477-488.

Alexander, J. C., \& Jacobs, R. N. (1998). Mass communication, ritual and civil society. In T. Liebes \& J. Curran (Eds.), Media, ritual, and identity (pp. 23-41). London: Routledge.

Alexander, J. C., \& Smith, P. (1993). The discourse of American civil society: A new proposal for cultural studies. Theory and Society, 22(2), 151-207.

Alexander, J. C., \& Smith, P. (2001). The strong program in cultural theory: Elements of a structural hermeneutics. In J. H. Turner (Ed.), Handbook of sociological theory (pp. 135-150). New York: Springer.

Almeling, R. (2011). Sex cells: The medical market for eggs and sperm. Berkeley and Los Angeles: University of California Press.

Anteby, M. (2010). Markets, morals, and practices of trade: Jurisdictional disputes in the US commerce in cadavers. Administrative Science Quarterly, 55(4), 606-638.

ARTInvestment.RU (2017). Art Market in Russia. Report 2016. https://artinvestment.ru/en/invest/art-marketrussia-reports/art_market_in_russia_report_2016.html. Accessed 31 Mar 2017.

Artprice. (2009). The Contemporary Art Market 2008/2009. The Artprice annual report. Lyon: Artprice.

Artprice. (2011). The Contemporary Art Market 2010/2011. The Artprice annual report. Lyon: Artprice.

ArtTactic. (2009). US \& European Contemporary art Market Confidence Report. London: ArtTactic Ltd..

ArtTactic. (2017). The south Asian art market report 2017. London: ArtTactic Ltd..

Aspers, P. (2009). Knowledge and valuation in markets. Theory and Society, 38(2), 111-131. 
Ayyappa Panicker, K. (2003). Indian narratology. New Delhi: Indira Gandhi National Centre for the Arts, Sterling Publishers.

Baker, W. E. (1990). Market networks and corporate behavior. American Journal of Sociology, 3, 589-625.

Bandelj, N. (2008). Economic objects as cultural objects: Discourse on foreign investment in post-socialist Europe. Socio-Economic Review, 6(4), 671-702.

Becker, H. S. (1984). Art worlds. Berkeley and Los Angeles: University of California Press.

Beckert, J. (2010). How do fields change? The interrelations of institutions, networks, and cognition in the dynamics of markets. Organization Studies, 31(5), 605-627.

Beckert, J. (2013). Imagined futures: Fictional expectations in the economy. Theory and Society, 42(3), 219-240.

Beckert, J., \& Rössel, J. (2013). The price of art: Uncertainty and reputation in the art field. European Societies, 15(2), 178-195.

Bernstein, A. (2014). Caution, religion! Iconoclasm, secularism, and ways of seeing in post-soviet art wars. Public Culture, 26(3 74), 419-448.

Blinder, A. S., Ehrmann, M., Fratzscher, M., De Haan, J., \& Jansen, D. J. (2008). Central bank communication and monetary policy: A survey of theory and evidence. Journal of Economic Literature, 46(4), 910-945.

Boje, D. M. (2001). Narrative methods for Organizational \& Communication Research. London: Sage Publications.

Bourdieu, P. (1989). Social space and symbolic power. Sociological Theory, 7(1), 14-25.

Bourdieu, P. (1993). The field of cultural production. Essays on art and literature. Cambridge: Polity Press.

Brosius, C. (2012). India's middle class: New forms of urban leisure, consumption and prosperity. London, New York, New Delhi: Routledge.

Brown, R. (2009). Art for a modern India, 1947-1980. Durham and London: Duke University Press.

Bydler, C. (2004) The Global Art World, Inc.: On the Globalization of Contemporary Art. Doctoral thesis. Figura Nova series, 32.

Campbell, J. L., \& Hall, J. A. (2015). Small states, nationalism and institutional capacities: An explanation of the difference in response of Ireland and Denmark to the financial crisis. European Journal of Sociology, 56(01), 143-174.

Chan, C. S. (2009). Creating a market in the presence of cultural resistance: The case of life insurance in China. Theory and Society, 38(3), 271-305.

Chan, C. S. (2012). Marketing death: Culture and the making of a life insurance market in China. Oxford: Oxford University Press.

Crane, D. (2009). Reflections on the global art market: Implications for the sociology of culture. Sociedade e Estado, 24(2), 331-362.

Cunliffe, A. L., \& Coupland, C. (2012). From hero to villain to hero: Making experience sensible through embodied narrative sensemaking. Human Relations, 65(1), 63-88.

Cunliffe, A. L., Luhman, J. T., \& Boje, D. M. (2004). Narrative temporality: Implications for organizational research. Organization Studies, 25(2), 261-286.

Dobbin, F. (2004). Introduction: The sociology of the economy. In F. Dobbin (Ed.), The sociology of the economy (pp. 1-25). New York: Russell Sage Foundation.

Dundes, A. (1997). Binary opposition in myth: The Propp/Levi-Strauss debate in retrospect. Western Folklore, $56(1), 39-50$.

Evans, S. (2008). Financial Crisis Cools Down Art Market. In Forbes. http://www.forbes.com/2008/10/31/christiessothebys-frieze-pf-art-in se 1031artmarket inl.html. Accessed 14 April 2014.

Fisher, W. R. (1985). The narrative paradigm: An elaboration. Communications Monographs, 52(4), 347-367.

Fligstein, N. (1996). Markets as politics: A political-cultural approach to market institutions. American Sociological Review, 61(4), 656-673.

Fligstein, N. (2002). The architecture of markets. An economic sociology of twenty-first-century capitalist societies. Princeton: Princeton University Press.

Fligstein, N., Brundage, J. S., \& Schultz, M. (2014). Why the Federal Reserve Failed to see the financial crisis of 2008: The role of "macroeconomics" as a sense making and cultural frame. IRLE Working Paper no. 111-14. http://irle.berkeley.edu/workingpapers/111-14.pdf. Accessed 1 Aug 2016.

Fourcade, M., \& Healy, K. (2007). Moral views of market society. Annual Review of Sociology, 33, $285-311$.

Gee, J. P. (1991). Memory and myth: A perspective on narrative. In A. McCabe \& C. Peterson (Eds.), Developing narrative structure (pp. 1-25). Hillsdale: Lawrence Erlbaum Associates.

Goebel, W., and Schabio, S. (2013). Locating postcolonial narrative genres (Vol. 43). New York: Routledge.

Goodwin, J. (Ed.). (2008). The international art Markets: The essential guide for collectors and investors. London and Philadelphia: Kogan Page.

Government of India (2014). Results-Framework Document for Ministry of Culture (2014-2015). http://www. indiaculture.nic.in/sites/default/files/rfd/RFD2014-15.pdf. Accessed 1 Aug 2016. 
Granovetter, M. (1985). Economic action and social structure: The problem of embeddedness. American Journal of Sociology, 481-510.

Halliday, W. R. (2014 [1933]). Indo-European folk-tales and Greek legend. Cambridge: Cambridge University Press.

Hernando, E. (2011) Art market crisis? ArtPulse Magazine. http://artpulsemagazine.com/art-market-crisis. Accessed 14 Apr 2014.

Herwitz, D. (2001). The idea of an art historical shape. English Studies in Africa, 44(1), 59-82.

Horowitz, N. (2011). Art of the deal. Contemporary art in a global financial market. Princeton: Princeton University Press.

InArt. (2016). Analytical report of the Russian contemporary art market. Moscow: AugustBorg.

Ithurbide, C. (2014). Beyond Bombay art district: Reorganization of art production into a polycentric territory at metropolitan scale, vol. 3. Belgeo: Revue belge de géographie.

Jindal, M. (2016). Indian narratology: A study of Salman Rushdie. IJAR, 2(3), 651-655.

Joshi, O. P. (1985). Sociology of Indian art. Jaipur: Rawat Publications.

Karpik, L. (2010). Valuing the unique: The economics of singularities. Princeton: Princeton University Press.

Kaushik, S. K. (1997). India's evolving economic model. American Journal of Economics and Sociology, 56(1), 69-84.

Khaire, M. (2011). The Indian fashion industry and traditional Indian crafts. Business History Review, 85(02), 345-366.

Khaire, M., \& Wadhwani, R. D. (2010). Changing landscapes: The construction of meaning and value in a new market category-Modern Indian art. Academy of Management Journal, 53(6), 1281-1304.

Kharchenkova, S., Komarova, N., \& Velthuis, O. (2015). Official art organizations in the emerging markets of China and Russia. In O. Velthuis \& S. B. Curioni (Eds.), Globalization of Markets for Contemporary art (pp. 78-101). Oxford: Oxford University Press.

Kholmogorova, O. V. (2014). Moskovskiye Performansi 1960-1990kh: Tendentsii, Dinamika, Geografiya. [Moscow performances of the 1960-1990s: Trends, dynamics, geography] in a.K. Florkovskaya and M.A. Busev (Eds.), Neofitsialniye Iskusstvo v SSSR 1950-1980e Godi [Unofficial Art in the USSR, 1950-1980] (pp. 53-64). Moskva: BuksMArt.

Komarova, N. (2015). The meanings of discounts in contemporary art Markets: The case of India. Cultural Sociology, 9(4), 567-582.

Komarova, N., \& Velthuis, O. (2017). Local contexts as activation mechanisms of market development: Contemporary art in emerging markets. Consumption Markets \& Culture, Online first, February 1, 2017, 1-21. https://doi.org/10.1080/10253866.2017.1284065 .

Koselleck, R. (2000). Critique and crisis: Enlightenment and the pathogenesis of modern society. Cambridge: MIT Press.

Kraeussl, R., \& Logher, R. (2010). Emerging art markets. Emerging Markets Review, 11(4), 301-318.

Lamont, M. (1992). Money, morals, and manners: The culture of the French and the American upper-middle class. Chicago: University of Chicago Press.

Law, J., Ruppert, E., \& Savage, M. (2011). The double social life of methods. CRESC.: Goldsmiths http://research.gold.ac.uk/7987/. Accessed 1 Aug 2016.

Lindstrom, N. (2015). Wither diversity of post-socialist welfare capitalist cultures? Crisis and change in Estonia and Slovenia. European Journal of Sociology, 56(01), 119-139.

Maines, D. R. (1993). Narrative's moment and Sociology's phenomena: Toward a narrative sociology. The Sociological Quarterly, 34(1), 17-38.

McAndrew, C. (2009). Globalisation and the art market. In Emerging economies and the art trade in 2008. Helvoirt: The European Fine Art Foundation (TEFAF).

McAndrew, C. (2010). The international art market 2007-2009. Trends in the Art Trade during Global Recession. Helvoirt: The European Fine Art Foundation (TEFAF).

McCloskey, D. N. (1990). If you're so smart: The narrative of economic expertise. Chicago: University of Chicago Press.

Menger, P. (1999). Artistic labor markets and careers. Annual Review of Sociology, 25, 541-574.

Menger, P. M. (2014). The economics of creativity: Art and achievement under uncertainty. Cambridge: Harvard University Press.

Milam, J. (2013). "Art girls": Philanthropy, corporate sponsorship, and private art museums in postcommunist Russia. Curator: The Museum Journal, 56(4), 391-405.

Monaghan, A. (2012). The end of the Putin era? The Carnegie Papers. Carnegie Endowment for International Peace. http://carnegieendowment.org/files/end_of_putin.pdf. Accessed 1 Aug 2016.

Morrill, C., \& Fine, G. A. (1997). Ethnographic contributions to organizational sociology. Sociological Methods \& Research, 25(4), 424-451.

Moulin, R. (1987). The French art market: A sociological view. New Brunswick: Rutgers University Press. 
Olson, S. R. (1999). Hollywood planet: Global media and the competitive advantage of narrative transparency. Mahwah, London: Routledge.

Peterson, K. (1997). The distribution and dynamics of uncertainty in art galleries: A case study of new dealerships in the Parisian art market, 1985-1990. Poetics, 25(4), 241-263.

Polanyi, L. (1979). So, what's the point? Semiotica, 25(3-4), 207-241.

Poulsen, N. (2012). Creative tensions: Contemporary fine art in the 'new' India. In A. P. De Costa (Ed.), A new India? Critical reflections in the long twentieth century (pp. 179-194). London: Anthem Press.

Pugh, A. J. (2013). What good are interviews for thinking about culture? Demystifying interpretive analysis. American Journal of Cultural Sociology, 1(1), 42-68.

Quemin, A. (2006). Globalization and mixing in the visual arts an empirical survey of 'high culture'and globalization. International Sociology, 21(4), 522-550.

Riessman, C. K. (1993). Narrative analysis, Vol. 30. London: Sage.

Robertson, I. (2011). A new art from emerging markets. Farnham: Lund Humphries.

Roitman, J. (2014). Anti-Crisis. Durham and London: Duke University Press.

Selina, E., \& Obukhova, S. (Eds.). (2013). Reconstruction 1990-2000. Exhibition catalogue. Moscow: August Borg.

Shevchenko, O. (2008). Crisis and the everyday in postsocialist Moscow. Bloomington and Indianapolis: Indiana University Press.

Slovaeva, N. (2014). Adresa: Gde i Kak Prokhodili Kvartirniye Vistavki v 1970-1980e. (addresses: Where and how apartment exhibitions happened in 1970-1980s) Artguide.com, December 3. http://www.artguide. com/posts/704. Accessed 11 Aug 2015.

Smith, B. H. (1980). Narrative versions, narrative theories. Critical Inquiry, 7(1), 213-236.

Sooudi, O. K. (2015). Morality and exchange in the Mumbai contemporary art world. In O. Velthuis \& S. B. Curioni (Eds.), Globalization of Markets for Contemporary art (pp. 264-284). Oxford: Oxford University Press.

Starodubtseva, Z. B. (2014). Neofitsialnoye Iskusstvo v Museyakh, Chastnikh Kollektsiyakh v Rossii i za Rubezhom v 1950-2010-e Godi. (unofficial art in museums, private collections in Russia and abroad in 1950-2010s) in a. K. Florkovskaya and M. A. Busev (Eds.), Neofitsialniye Iskusstvo v SSSR 1950-1980e Godi (unofficial art in the USSR, 1950-1980) (pp. 402-439). Moskva: BuksMArt.

Vaid, D. (2014). Caste in contemporary India: Flexibility and persistence. Annual Review of Sociology, 40, 391-410.

Vaisey, S. (2014). Is interviewing compatible with the dual-process model of culture? American Journal of Cultural Sociology, 2(1), 150-158.

Velthuis, O. (2003). Symbolic meanings of prices: Constructing the value of contemporary art in Amsterdam and New York galleries. Theory and Society, 32(2), 181-215.

Velthuis, O. (2005). Talking prices. Symbolic meanings of prices on the market for contemporary art. Princeton: Princeton University Press.

Velthuis, O. (2010). The return of the 90s. The Art Market in Times of Crisis. Transcription. New York: JEQU. http://www.jequ.org/files/olav-velthuis.pdf.

Velthuis, O. (2011) What crisis? Super rich are still buying. The Art Newspaper. http://www.theartnewspaper. com/articles/What-crisis-Super-rich-are-still-buying/25218. Accessed 14 Apr 2014.

Velthuis, O., \& Curioni, S. B. (Eds.). (2015). Globalization of Markets for Contemporary art. Oxford: Oxford University Press.

Wherry, F. F. (2008). Global markets and local crafts: Thailand and Costa Rica compared. Baltimore: Johns Hopkins University Press.

Wherry, F. F. (2014). Analyzing the culture of markets. Theory and Society, 43(3-4), 421-436.

White, H. (1973). Metahistory: The historical imagination in nineteenth-century Europe. Baltimore and London: Johns Hopkins University.

White, H. (1980). The value of narrativity in the representation of reality. Critical Inquiry, 7(1), 5-27.

White, H. (1981). Where do markets come from. Advances in Strategic Management, 17(2), 323-350.

White, H. C., \& White, C. A. (1965). Canvases and careers: Institutional change in the French painting world. Chicago: University of Chicago Press.

Yanitsky, O. (2013). From civic protest to political reform: The case of Russia. Centre for the Study of Politics and Society - WP Series, 3, 1-27.

Yankovskaya, G., \& Mitchell, R. (2006). The economic dimensions of art in the Stalinist era: Artists' cooperatives in the grip of ideology and the plan. Slavic Review, 65(4), 769-791.

Zelizer, V. A. (1979). Morals and markets. The development of life Insurance in the United States. New York: Columbia University Press. 
Zelizer, V. A. (1999). Multiple markets: Multiple cultures. In J. C. Alexander \& N. J. Smelser (Eds.), Diversity and its discontents: cultural conflict and common ground in contemporary American Society (pp. 193212). Princeton: Princeton University Press.

Zelizer, V. A. (2000). The purchase of intimacy. Law \& Social Inquiry, 25(3), 817-848.

Zelizer, V. A. (2010). Economic lives: How culture shapes the economy. Princeton: Princeton University Press.

Nataliya Komarova is a $\mathrm{PhD}$ researcher at the Amsterdam Institute of Social Science Research, University of Amsterdam and a lecturer at the Erasmus School of History, Culture and Communication, Erasmus University Rotterdam. Her current research focuses on the institutional dynamics of developing art markets and art organizations from broader economic and cultural sociological perspectives. She is interested in the processes of meaning-making within organizations in relation to local socio-political contexts and in the interrelation between structural and cultural dimensions of organizational fields. Her publications include "The Meanings of Discounts in Contemporary Art Markets" (in Cultural Sociology journal) and "Local contexts as activation mechanisms of market development" (in Consumption Markets and Culture, co-authored with Olav Velthuis). 